УДК 355.72(477)(091)

DOI: $10.33099 / 2707-1383-2020-38-4-54-61$

Филь О.М., кандидат історичних наук, старший науковий співробітник наукового відділу інформачійно-музейної діяльності, Національний військово-історичний музей України (м. Київ, Україна).

ORCID: https://orcid.org/0000-0002-0662-8654

\title{
ТУТ ВІЧНО ЗВУЧАТИМУТЬ ЇХ ІМЕНА... МЕМОРІАЛЬНИЙ КОМПЛЕКС МІНІСТЕРСТВА ОБОРОНИ УКРАЇНИ
}

\begin{abstract}
У статті вперше досліджено та проаналізовано діяльність Меморіального комплексу Міністерства оборони України, як єдиного місия в країні, де зібрані та назавжди вписані до історії імена загиблих захисників держави. Автор, користуючись, у першу чергу, матеріалом, зібраним, опрацьованим та оприлюдненим співробітниками Національного військово-історичного музею України під час підготовки до відкриття Меморіального комплексу, а також однотипними, здебільшого репортажними та інформаційними публікаціями в ЗМI, щуо з'являлися під час проведення офіційних заходів, не тільки досить трунтовно та детально висвітлює діяльність ијього унікального меморіального закладу, але й відзначає його роль, як важливого чинника начіональної ідентичності та місия збереження в національній пам'яті жертовності і подвигу українських військовиків, які віддали життя, захищаючи незалежність, суверенітет і територіальну цілісність держави від російського агресора.
\end{abstract}

Ключові слова: Меморіальний комплекс, Міністерство оборони Украӥни, Збройні Сили Украӥни, Міністерство внутрішніх справ Украӥни, Зала пам'яті, Книга пам'яті.

Виклад основного матеріалу. Меморіальний комплекс Міністерства оборони України було зведено у 2018 році. Від самого початку він був збудований з метою вшанування пам'яті військовослужбовців Збройних Сил України, які загинули за свободу, незалежність та територіальну цілісність України, світовий мир та порядок.

Ініціатива створення комплексу належить Міністру оборони України генералу армії Степану Полтораку, який очолював МОУ 314 жовтня 2014 року по 29 серпня 2019 року. Згодом задум очільника оборонного відомства було оформлено у відповідний Наказ Міністерства оборони України за № 86 від 4 березня 2019 року «Питання вшанування пам'яті військовослужбов- ців Збройних Сил України, які загинули за свободу, незалежність і територіальну цілісність України та під час проведення міжнародних операцій з підтримання миру та безпеки» [1]. Відповідний наказ було погоджено з міністерствами культури та соціальної політики України.

Окрім того персоналом Департаменту військової освіти, науки, соціальної та гуманітарної політики Міністерства оборони України було відпрацьовано порядок щоденного проведення заходів щодо вшанування пам'яті військовослужбовців Збройних Сил України, які загинули за свободу, незалежність і територіальну цілісність України та під час проведення міжнародних операцій з підтримання миру та безпеки» [1]. 
У вищезазначеному Порядку визначені загальні положення, де позначені складові Меморіального комплексу, зокрема Зала пам'яті, де експонується Книга пам'яті, Пам'ятний знак - Дзвін пам'яті та плац для проведення урочистих церемоніальних заходів. Окрім того в Порядку визначене коло посадових осіб, які мають брати участь в урочистих церемоніальних заходах.

У Порядку прописано і сам хід проведення Заходів та дії посадових осіб, тобто своєрідний сценарний план або ритуал. Крім того Порядком визначено організацію відвідування Меморіального комплексу.

Варто зазначити, що задум очільника вітчизняного оборонного відомства свого часу отримав підтримку з боку керівництва Держави. Таким чином, реалізувавши створення Меморіального комплексу, Україна мала б долучилася до світової практики вшанування полеглих військовослужбовців.

Звичайно, перед проєктуванням Меморіального комплексу активно вивчався європейський та світовий досвід зведення подібних меморіальних споруд. Зокрема, при створенні Зали пам'яті було використано канадський досвід. Подібна зала існує в столиці цієї країни - місті Оттава. Варто зазначити, що хронологія військових втрат збройних сил цієї північноамериканської держави відображена в кількатомному виданні книг пам'яті, починаючи з 1916 року. А це нагадаю, і Перша, і Друга світові війни, а також участь у багатьох миротворчих операціях, що проводилися під егідою ООН, НАТО та інших міжнародних організацій, у гарячих точках світу i, де Канада брала активну участь.

Після грунтовного та деталізованого обговорення і внесення відповідних пропозицій з боку зацікавлених сторін, Центральним проєктним інститутом Міністерства оборони України було підготовлено проєкт Меморіального комплексу. Варто зауважити, що Центральний проєктний інститут $€$ профільним закладом 3 проєктування споруд оборонного та спеціального призначення.

До розробки концепту Зали пам'яті був залучений також відомий український архітектор, автор проєктів багатьох сучасних громадських і комерційних будівель Андрій Пашенько. А сам проєкт був реалізований військовослужбовцями Державної спеціальної служби транспорту Міністерства оборони України [2].

Варто зазначити, що ідея внутрішнього оздоблення та інформаційного наповнення Зали пам'яті належить співробітникам Національного військово-історичного музею України. Саме співробітники музею на чолі 3 директором Андрієм Ільєнком та його заступником 3 наукової роботи, знаним ученим-істориком Ярославом Тинченком, здійснювали формування та виготовлення Книги пам'яті, а також табличок з іменами загиблих і, відповідно їх монтаж на пілонах Зали пам'яті.

Користуючись музичною термінологією, Меморіальний комплекс мав втілити головний лейтмотив - стати єдиним місцем в державі, де були б зібрані та назавжди вписані до новітньої історії нашої країни імена загиблих захисників України. Зведення цього своєрідного Пантеону пам'яті мало б започаткувати нову традицію для Українського війська - важливо пам'ятати кожного, персонально, називати імена, не ховаючи їх в сухі цифри статистики втрат. Це стало не тільки основною ідеєю, але й ідеологією авторів цього неповторного проєкту.

Щодо втрат, то вони насамперед відображені на пілонах Зали пам'яті. Станом на 31 грудня 2020 року на пілонах Зали пам'яті позначені імена 2738 військовос- 
лужбовців Збройних Сил України. А відкривають цей скорботний список військовослужбовці ЗСУ, які загинули під час проведення миротворчих операцій під егідою ООН, НАТО та інших міжнародних організацій. Варто зазначити, що починаючи з 1992 року в міжнародних операціях 3 підтримання миру і безпеки взяли участь близько 45000 українських військовослужбовців, з яких 55 загинуло [3].

Так у Залі пам'яті, зокрема позначені імена військовослужбовців ЗСУ, які загинули у складі сил OOH з охорони (UNPROFOR). Це - Миротворча місія $\mathrm{OOH}$ в Хорватії та в Боснії і Герцеговині під час Югославських воєн, всього скорботний список складає 10 осіб. У складі сил $\mathrm{OOH}$ - місія $\mathrm{OOH}$ в Анголі (MONUA) - 1 особа. У складі Сил стабілізації (SFOR) у Боснії і Герцеговині загинуло 2 особи. У Залі пам'яті закарбовані імена 3 осіб, які загинули в складі Міжнародних сил з підтримки миру в Косово (KFOR). Під час проведення операції $\mathrm{OOH} з$ підтримання миру в Сьєра-Леоне загинуло шестеро українців. Всі вони занесені до скорботного списку Зали пам'яті. Імена трьох військовослужбовців ЗСУ, які брали участь у складі Місії ООН у Ліберії також представлені в Залі пам'яті.

Далі на пілонах Зали пам'яті відображені імена військовослужбовців ЗСУ, які загинули під час проведення Антитерористичної операції та Операції об'єднаних сил на сході України.

Так, 2014 рік позначений іменами 1269 осіб, 2015 рік - 726 особами, 2016 рік - 236 іменами загиблих, 2017 рік - 210, 2018 - 120, 2019 рік 100 іменами. На пілонах Пантеону пам'яті також позначені імена військовослужбовців Збройних Сил України внесених до скорботного списку в 2020 році. Станом на 31 грудня 2020 року в Залі пам'яті 49 імен воїнів, які були внесені на пілони
Зали пам'яті та до Книги пам'яті в 2020 році.

Варто також зазначити, що облік загиблих військовослужбовців Збройних Сил України ведеться відповідним структурним підрозділом Генерального штабу Збройних Сил України. Саме військовослужбовці цього структурного відділу готують список загиблих, рекомендованих до внесення до Зали пам'яті. Після процедури погодження цей список надходить до Національного військово-історичного музею України. Співробітники цього закладу виготовляють таблички 3 іменами воїнів та здійснюють їх монтаж на пілони Зали пам'яті. Внесення імен загиблих до Книги пам'яті здійснюється раз на рік в серпні-вересні. Нині на подіумі знаходиться третя за рахунком Книга пам'яті ЗСУ (третя редакція)

Дикторські тексти, де позначені імена загиблих складають та озвучують співробітники Національного військово-історичного музею України. Звукозапис дикторських текстів з переліком загиблих на кожний день та відеоряд із зображенням фотосвітлин і короткими відомостями про воїнів після узгодженням зі співробітниками музею здійснюють та монтують співробітники Центральної телерадіостудії Мiністерства оборони України.

Загальну координацію щоранкових ритуалів в Меморіальному комплексі здійснюють співробітники Департаменту соціального та гуманітарного забезпечення під керівництвом Назіма Агаєва, а співробітники відділу військово-патріотичного виховання вищезазначеного структурного підрозділу разом з фахівцями Головного управління морально-психологічного забезпечення Генерального штабу Збройних Сил України та Департаменту юридичного забезпечення проводять відповідну роботу 3 членами родин загиблих воїнів, відповідно до своїх функціональних повноважень. 
Щодо порядку внесення імен військовослужбовців Збройних Сил України до Книги пам'яті i, відповідно розташування їх на пілонах Зали пам'яті, то варто зазначити, що Генеральний штаб Збройних Сил України подає списки загиблих ЗСУ, які належать до бойових втрат. Насамперед, це - загиблі внаслідок безпосереднього зіткнення 3 противником (ураження його зброєю), а також військовослужбовці, які померли від поранень внаслідок ведення бойових дій.

У Залі пам'яті на пілонах та у Книзі пам'яті позначені імена 28 воїнів Збройних Сил України удостоєних посмертно звання Героя України.

На пілонах Зали пам'яті і в Книзі пам'яті ЗСУ позначені імена дев'яти жінок-військовослужбовців.

Варто також зауважити, що прізвища загиблих відображені на пам'ятних металевих табличках, що за своєю формою нагадують особові іменні нашивки військовослужбовців ЗСУ на одностроях. Розташовані вони, згідно хронологічних меж, тобто по роках, в алфавітному порядку.

У центрі Зали на спеціальному подіумі знаходиться Книга пам'яті, куди внесені імена загиблих військовослужбовців Збройних Сил України. Вітраж вгорі зали, виготовлений за технологією відомого американського художника та дизайнера Луїса Тіффані, покликаний перенести проекцію емблеми ЗСУ у формі малинового хреста, на подіум з Книгою пам'яті.

Книга побудована за принципом календаря - один іiі розворот відповідає одному дню у році. Щоранку під час урочистого ритуалу відкривається нова сторінка на якій зазначені імена тих, хто загинув у цей день. $€$ у цій книзі дні найбільших втрат. Це, передусім, 29 серпня. На розвороті цього дня закарбовані прізвища 148 військовослужбовців Збройних Сил України, переважна більшість яких загинула в 2014 році під час виходу із оточення під Іловайськом.

20 січня позначене прізвищами 51 військовослужбовця. У цей день у 2015 році завершилася 242-денна героїчна оборона Донецького аеропорту.

Рясніє скорботними рядками прізвищ і 14 червня. Саме в ніч на цей день 2014 року терористи збили військово-транспортний літак Іл-76 на борту якого знаходилося 49 десантників та льотчиків. Усього ж у Книзі пам'яті військовослужбовців $3 С У$ цей день позначений іменами 57 воїнів.

5 вересня ще одна печальна віха в історії Збройних Сил України. Цього дня у 2014 року розгорілися криваві бої з російським агресором на підступах до Луганська, коли буквально в останні години перед перемир'ям загинуло 42 бійці. Ще три військовослужбовці цього дня загинули, відповідно в 2016, 2018 та 2019 роках.

Але $є$ у Книзі пам'яті ЗСУ і 22 дні, коли Збройні Сили України не зазнавали втрат. Зауважу, що на момент відкриття Меморіального комплексу, таких днів, що згодом отримали назву днів тиші, було 32.

Варто зазначити, що до проєктування Меморіального комплексу долучились і волонтери. Саме їм належить ідея облаштування зовнішнього майданчика. На ньому розташована товста зігнута металева пластина, імітована під броню, яка уособлює тіло українського війська. Пластина пробита різними калібрами зброї. Отвори у ній дійсно відповідають реальним пошкодженням від влучання боєприпасів. Увінчує композицію Дзвін пам'яті, виготовлений на кошти небайдужих громадян. На дзвоні імітована кіптява, ніби він вийшов 3 вогню, загартований ним.

Меморіальний комплекс було урочисто відкрито 14 жовтня 2018 року в День захисника України за присутності керівництва 
держави. Саме цього дня вперше прозвучало ім'я військовослужбовця Збройних Сил України, який загинув під час проведення Антитерористичної операції. Солдат 51-ї окремої механізованої бригади (нині, це 14-та окрема механізована бригада імені князя Романа Великого) Михайло Рибак [2] відкрив скорботний список імен військовослужбовців, які загинули за свободу, незалежність і територіальну цілісність України та під час проведення міжнародних операцій з підтримання миру і безпеки, які почали озвучуватися в Залі пам'яті Меморіального комплексу.

Тепер тут щоденно відбувається ритуал вшанування захисників України, внесених до Книг пам'яті. Ритуал чітко виписаний і відбувається за затвердженим сценарієм. За сигналом труби розпочинається висування роти Почесної варти зі складу Окремого президентського полку імені Богдана Хмельницького. Вартові розміщуються по периметру комплексу, а дві окремі групи стають до стели із дзвоном та до Книги Пам'яті. Труба і барабан виконують твір «Шана» - це заклик до тиші. Після слів диктора, який оголошує відповідний день, командир почесної варти перегортає сторінку книги на ту, що відповідає сьогоднішньому дню, далі диктор або зачитує імена загиблих, оголошує день тиші. У пам'ять кожного $з$ полеглих героїв лунає удар дзвону та військовий салют, що є обов'язковою частиною військових почестей.

Варто зазначити, що у 2019 році керівництво Міністерства оборони України відгукнулося на звернення очільника Міністерства внутрішніх справ України Арсена Авакова, щодо розташування Книги пам'яті працівників органів системи Міністерства внутрішніх справ України та співробітників Служби безпеки України, які загинули за свободу, незалежність і територіальну цілісність України та під час проведення міжнародних операцій з підтримання миру та безпеки в Залі пам'яті Меморіального комплексу та залучення військовослужбовців, правоохоронців та працівників МВС та СБУ до проведення відповідних церемоніальних заходів.

Починаючи з 6 серпня 2019 року в Залі пам'яті тепер звучать імена військовослужбовців, правоохоронців та працівників Міністерства внутрішніх справ України, Національної поліції України, Служби безпеки України, Національної гвардії України, Державної прикордонної служби України та Державної служи України з надзвичайних ситуацій.

У Книзі пам'яті працівників органів системи Міністерства внутрішніх справ України та співробітників Служби безпеки України, що також побудована за принципом календаря позначені імена 448 військовослужбовців, правоохоронців та працівників. У скорботному списку позначені імена 194 воїнів, співробітників та працівників НГУ, 132 - МВС, $70-$ ДПСУ, ДСНС 23 та 24 - СБУ. У вищезазначеній Книзі пам'яті позначені імена 14 Героїв України удостоєних цього звання посмертно, а саме представників Національної гвардії України - 5 осіб, Служби безпеки України 4 особи, Державної прикордонної служби України - 3 особи, Національної поліції України - 1 особа, а також ГУ МВС України -1 особа.

Всього в Книзі пам'яті працівників органів системи Міністерства внутрішніх справ України та співробітників Служби безпеки України іменами загиблих позначені 148 сторінок з 366. День найбільших втрат — 29 серпня, позначений іменами 76 воїнів.

Внесення імен працівників органів системи Міністерства внутрішніх справ України та співробітників Служби безпеки України до загального скорботного списку, 
що озвучується в Залі пам'яті, відповідно скоротило кількість днів тиші. На сьогодні їх залишилося всього шістнадцять [4]. У ці дні не чути імен загиблих та не лунає меморіальний дзвін і військовий салют. Зазначу, що найбільше таких днів у грудні - чотири. Жодного дня тиші немає влітку.

Окрім того зросла і кількість прізвищ у списках загиблих воїнів. Відтепер 29 серпня Дзвін пам'яті лунає 224 рази, скільки ж раз здійснюється і військовий салют [2]. Варто зауважити, що саме цей день позначений на календарі нашої держави, як День пам'яті захисників України, які загинули в боротьбі за незалежність, суверенітет і територіальну цілісність нашої держави. Відповідний Указ за № 621/2019 було підписано Президентом України 23 серпня 2019 року. А 29 серпня 2019 року Президент України Володимир Зеленський взяв участь у заходах зі вшанування пам'яті захисників України на території Меморіального комплексу Міністерства оборони України. Зауважу, що сам перелік імен загиблих під час проведення ритуалу цього дня тривав майже 38 хвилин.

Меморіальний комплекс Міністерства оборони України за час свого існування здійснив 816 ритуали (станом на 31 грудня 2020 року) із вшанування пам'яті загиблих захисників України, які відвідали понад 68 тисяч осіб. Меморіал відвідують родичі загиблих героїв, друзі, побратими, колеги, керівники силових відомств, політики, відомі люди, закордонні гості... [5].

Нині Меморіальний комплекс разом зі Стіною пам'яті полеглих за Україну, що змонтована в Києві на мурі кафедрального собору Православної церкви України Михайлівського Золотоверхого монастиря вздовж вулиці Трьохсвятительської, став по справжньому національним меморіалом. До речі, Стіна пам'яті полеглих за Україну стала спільною роботою Укра- їнської православної церкви Київського патріархату, Національного військово-історичного музею України, редакції сайту «Книга пам'яті полеглих за Україну», а також історико-культурного товариства «Оберіг часу».

Варто зазначити, що крім Книги пам'яті та Дзвону пам'яті справжнім символом Меморіального комплексу став і вірш, написаний мамою старшого сержанта Олександра Дзеха - бійця 72-ї окремої механізованої бригади імені Чорних Запорожців, який загинув 19 липня 2014 року районі села Маринівка Донецької області.

У вірші мами Олександра Дзеха - Тетяни Меджидової відображено не тільки біль від втрати найдорожчої людини, але й найвищу жертовність воїнів, які боронять Вітчизну від ворога, а також впевненість, що подвиги героїв назавжди залишаться в народній пам'яті:

Герої не вмирають,

А йдуть на небеса

I там на них чекає

Небесна вся краса.

Блакитне небо, поле,

Що житом колосить,

Це - прапор України

I він нас захистить!

А хлопців проводжають

В останню їхню путь...

Герої не вмирають -

Вони в віках живуть! [6].

Цей вірш увійшов до збірки віршів Тетяни Меджидової «Як болить мені війна». До речі, сама збірка віршів була презентована в Залі пам'яті 12 грудня 2018 року після ранкового ритуалу. Мама Олександра Дзеха - Тетяна Меджидова почала писати вірші після загибелі сина.

Віднині цей вірш лунає кожного дня в стінах Зали пам'яті Меморіального комплексу під час проведення ранкових ритуалів зі вшанування пам'яті полеглих героїв... 
Отже, у вітчизняному оборонному відомстві України глибоко переконані, що і Меморіальний комплекс і урочистий ритуал вшанування загиблих залишатимуться незмінними та нагадуватимуть всім про шанобливе ставлення держави і українського народу до своїх загиблих захисників.

Висновок. До недавнього часу Україна не мала єдиного місця в державі, де були б зібрані та увіковічені імена воїнів, які загинули за свободу, незалежність та територіальну цілісність України, світовий мир та порядок.

14 жовтня 2018 року в День захисника України за ініціативи керівника оборонного відомства відповідний Меморіальний комплекс було відкрито. Від самого початку він мав слугувати місцем вшанування пам'яті лише військовослужбовців Зброй- них Сил України. Однак з набуттям розголосу Меморіальний комплекс Міністерства оборони України в свідомості українців поступово трансформувався в єдине місце в державі, де вшановується пам'ять захисників України. А розташування Книги пам'яті працівників органів системи Міністерства внутрішніх справ України та співробітників Служби безпеки України в Залі пам'яті, а також озвучення їхніх імен, а також імен добровольців-захисників України, під час проведення щоденних ритуалів, остаточно закріпив за Меморіальним комплексом Міністерства оборони України не тільки офіційний статус місця, де вшановується пам'ять загиблих воїнів, але звання дійсно національного меморіалу, що разом зі Стіною пам'яті полеглих за Україну нині складають місця всенародної шани та скорботи.

Fyl O. M. candidate of historical sciences,

Senior Research of scientific department of information and museum activities of the National Military Historical Museum of Ukraine (Kyiv, Ukraine) ORCID: https://orcid.org/0000-0002-0662-8654

\section{THEIR NAMES WILL SOUND FOREVER... MEMORIAL COMPLEX OF THE MINISTRY OF DEFENSE OF UKRAINE}

The Memorial Complex of the Ministry of Defense of Ukraine was built with the aim of honoring the memory of soldiers of the Armed Forces of Ukraine who died for the freedom, independence and territorial integrity of Ukraine, world peace and order.

Using musical terminology, the Memorial Complex should realize the main leitmotif - to become the only place in the country where the names of the fallen defenders of Ukraine would be collected and forever inscribed in history. The construction of this kind of Pantheon of Memory should start a new tradition for Ukrainian army - it is important to remember everyone, personally, say the names, without hiding them in the dry numbers of loss statistics. This became the main idea and ideology of the authors of this unique project. 
The Memorial Complex was grand opened on October 14, 2018 on the Day of the Defender of Ukraine in the presence of leadership of the country. That was the day it was first heard the name of a soldier of the Armed Forces of Ukraine who died during the Anti-Terrorist Operation was first announced. Mykhailo Rybak, a soldier of the 51st Separate Mechanized Brigade (now the 14th Separate Mechanized Brigade named after Prince Roman the Great), opened a mourning list of names of soldiers who died for the freedom, independence and territorial integrity of Ukraine and during international peacekeeping operations and security, which began to be announced in the Memorial Hall of the Memorial Complex.

The Memorial Complex together with the Wall of Remembrance of the Fallen for Ukraine, which was erected in Kyiv on the walls of the Cathedral of the Orthodox Church of Ukraine - St. Michael's GoldenDomed Monastery along Trohsvyatitelskaya Street, has become a real national memorial.

The authors and initiators of the Memorial Complex project are deeply convinced that the solemn ritual of honoring the dead will remain unchanged and will remind everyone of the respectful attitude to the country and Ukrainians to their fallen defenders.

Keywords: Memorial complex, Ministry of Defense of Ukraine, Military Forces of Ukraine, Ministry of Internal Affairs of Ukraine, Hall of Memory, Book of Memory.

\section{СПИСОК ВИКОРИСТАНИХ ДЖЕРЕЛ І ЛІТЕРАТУРИ}

1. zakon.rada.gov.ua/lavs/show/z0312-19\#Text

2. Филь О. М. «Тут вічно звучатимуть їх імена...»// Українське військо: сучасність та історична ретроспектива /Збірник матеріалів/Всеукраїнська науково-практична конференція. - 2019. - С. 43.

3. https://www.mil.gov.ua/diyalnist/mirotvorchist/

4. https://www.yotubube.com/watch?v=8fkVsSAb9FM

5. armyinform.com.ua/2019/09/2678-tablychok-z-imenamy-zagyblyh-ustanovleno-u-zalipamyati-minoborony/

6. Тетяна Меджидова. Як болить мені війна./Т. Меджидова. - К.: 2018 . - С. 50. 